\title{
Neuraminidase Inhibitors from the Fermentation Broth of Phellinus linteus
}

\author{
Byung Soon Hwang', Myeong-Seok Lee', Seung Woong Lee', In-Kyoung Lee', Geon-Sik Seo', Hwa Jung \\ Choi $^{3}$ and Bong-Sik Yun ${ }^{1, *}$ \\ ${ }^{1}$ Division of Biotechnology and Advanced Institute of Environment and Bioscience, Chonbuk National University, Iksan 570-752, Korea \\ ${ }^{2}$ Korea National College of Agriculture and Fisheries, Hwaseong 445-760, Korea \\ ${ }^{3}$ Department of Beauty Science, Kwangju Women's University, Gwangju 506-713, Korea
}

\begin{abstract}
During a search for neuraminidase inhibitors derived from medicinal fungi, we found that the fermentation broth of Phellinus linteus exhibited potent neuraminidase inhibitory activity. Through bioassay-guided fractionation, two active compounds were purified from the ethyl acetate-soluble portion of the fermentation broth of $P$. linteus. These structures were identified as inotilone (1) and 4-(3,4-dihydroxyphenyl)-3-buten-2-one (2) by spectroscopic methods. Compounds 1 and 2 inhibited H1N1 neuraminidase activity with $\mathrm{IC}_{50}$ values of 29.1 and $125.6 \mu \mathrm{M}$, respectively, in a dose-dependent manner. They also exhibited an antiviral effect in a viral cytopathic effect reduction assay using MDCK cells. These results suggest that compounds $\mathbf{1}$ and $\mathbf{2}$ from the culture broth of $P$. linteus would be good candidates for the prevention and therapeutic strategies towards viral infections.
\end{abstract}

Keywords 4-(3,4-Dihydroxyphenyl)-3-buten-2-one, Anti-influenza agent, Inotilone, Neuraminidase inhibitor, Phellinus linteus

Influenza viruses are enveloped RNA viruses that belong to the family Orthomyxoviridae, and cause significant morbidity and mortality in humans through epidemics or pandemics [1]. Influenza viruses are classified into various serotypes on the basis of two surface glycoproteins: hemagglutinin and neuraminidase. Neuraminidase (EC 3.2.1.18) plays an important role in viral proliferation and is therefore a drug target for prevention of the spread of influenza [2]. Currently, the preferred treatment for influenza virus infection is the use of neuraminidase inhibitors such as oseltamivir (Tamiflu) and zanamivir (Relenza) [3]. However, toxicity due to long-term exposure to these drugs and the appearance of viral strains that are resistant to these antiviral drugs highlight the urgent need for next-generation neuraminidase inhibitors [4].

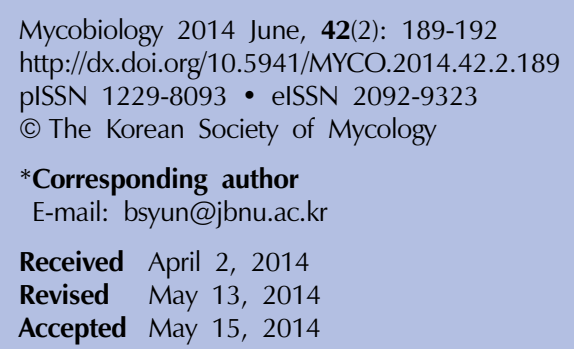

(a) This is an Open Access article distributed under the terms of the Creative Commons Attribution Non-Commercial License (http:// creativecommons.org/licenses/by-nc/3.0/) which permits unrestricted non-commercial use, distribution, and reproduction in any medium, provided the original work is properly cited.
Phellinus linteus is a species of mushroom belonging to the Hymenochaetaceae family, which is indigenous mainly to tropical regions of America, Africa and East Asia [5]. It is one of many medicinal mushrooms that have been widely used in East Asia, especially in Korea, China, and Japan, as health booster and ancient herbal medicine [6]. $P$. linteus is known as Sangwhang in Korea [7] and produces abundant bioactive compounds such as protocatechuic acid, caffeic acid, hispidin, davallialactone, hypholomine $\mathrm{B}$, interfungins $\mathrm{A}$, and inoscavin $\mathrm{A}$ [8-11]. The extract and compounds of $P$. linteus exhibit various biological activities including anti-cancer, anti-oxidative, anti-angiogenic, antiinflammatory and anti-viral effects [6, 12-17]. During the search for neuraminidase inhibitors from medicinal fungi, two neuraminidase inhibitors were isolated from the fermentation broth of P. linteus (Fig. 1). This paper describes the isolation,<smiles>CC(=O)/C=C/c1ccc(O)c(O)c1</smiles>

Fig. 1. Structures of compounds 1 (inotilone) and 2 (4-(3,4dihydroxyphenyl)-3-buten-2-one). 
structure determination, and neuraminidase inhibitory activity of these compounds.

$P$. linteus was obtained from the Korea National College of Agriculture and Fisheries, Korea. The strain was fermented on potato dextrose broth $(26 \mathrm{~L})$ at $27^{\circ} \mathrm{C}$ for 30 days. The fermentation broth was partitioned with ethyl acetate by vigorous shaking, and the ethyl acetate-soluble portion exhibited potent neuraminidase inhibitory activity at the concentration of $50 \mu \mathrm{g} / \mathrm{mL}$. Following the concentration of the ethyl acetate-soluble portion under reduced pressure, the concentrate was subjected to a Sephadex LH-20 (Pharmacia, Uppsala, Sweden) column and eluted with methanol resulting in two active fractions. A Sephadex LH-20 column with $70 \%$ aqueous methanol was used for chromatography of one fraction, followed by purification with preparative reversedphase high-performance liquid chromatography (HPLC) with $60 \%$ aqueous methanol $/ 0.04 \%$ trifluoroacetic acid, which resulted in compound $\mathbf{1}(6.8 \mathrm{mg})$. The other fraction was purified by Sephadex LH-20 column chromatography eluted with $70 \%$ aqueous methanol, followed by preparative reversed-phase HPLC using the same solvent used for compound $\mathbf{1}$, to afford compound $2(6.3 \mathrm{mg})$.

The structure of compound $\mathbf{1}$ was determined by the mass as well as the ${ }^{1} \mathrm{H}$ and ${ }^{13} \mathrm{C}$ nuclear magnetic resonance (NMR) measurements. The molecular weight of compound 1 was established by the electrospray ionization (ESI)-mass measurement, which provided a quasi-molecular ion peak at $m / z 219.0[\mathrm{M}+\mathrm{H}]^{+}$, suggesting a molecular weight of 218. The ${ }^{1} \mathrm{H}$ NMR spectrum of compound $\mathbf{1}$ in $\mathrm{CD}_{3} \mathrm{OD}$ exhibited signals due to $\delta 7.34(1 \mathrm{H}, \mathrm{d}, J=2.0 \mathrm{~Hz}, \mathrm{ArH})$, $7.16(1 \mathrm{H}, \mathrm{dd}, J=8.4,2.0 \mathrm{~Hz}, \mathrm{ArH}), 6.80(1 \mathrm{H}, \mathrm{d}, J=8.4 \mathrm{~Hz}$, $\mathrm{ArH}), 6.49(1 \mathrm{H}, \mathrm{s}, \mathrm{CH}), 5.80(1 \mathrm{H}, \mathrm{s}, \mathrm{CH})$, and $2.55(3 \mathrm{H}, \mathrm{s}$, $\mathrm{CH}_{3}$ ). In the ${ }^{13} \mathrm{C}$ NMR spectrum, twelve carbons were evident including a carbonyl carbon at $\delta 187.0$, four oxygenated $\mathrm{sp}^{2}$ carbons at $\delta 180.9,148.4,145.7$, and 144.6, five $\mathrm{sp}^{2}$ methine carbons at $\delta 123.1,118.2,116.2,112.3,105.7$, one $\mathrm{sp}^{2}$ quaternary carbon at $\delta 125.0$, and one methyl carbon at $\delta$ 15.9. Consequently, compound $\mathbf{1}$ was identified as inotilone by comparing measured ${ }^{1} \mathrm{H}$ and ${ }^{13} \mathrm{C}$ NMR spectra with those reported in the literature [18].

The structure of compound $\mathbf{2}$ was determined by mass and ${ }^{1} \mathrm{H}$ NMR measurements. The molecular weight of compound 2 was established by the ESI-mass, which provided a quasi-molecular ion peak at $m / z 177.0[\mathrm{M}-\mathrm{H}]^{-}$, suggesting a molecular weight of 178 . The ${ }^{1} \mathrm{H}$ NMR spectrum of compound 2 in $\mathrm{CD}_{3} \mathrm{OD}$ exhibited signals due to $\delta 7.51$ $(1 \mathrm{H}, \mathrm{d}, J=16.4 \mathrm{~Hz}), 7.07(1 \mathrm{H}, \mathrm{d}, J=2.4 \mathrm{~Hz}), 6.98(1 \mathrm{H}, \mathrm{dd}$, $J=2.4,8.4 \mathrm{~Hz}), 6.78(1 \mathrm{H}, \mathrm{d}, J=8.4 \mathrm{~Hz}), 6.54(1 \mathrm{H}, \mathrm{d}, J=$ $16.4 \mathrm{~Hz})$, and $2.32\left(3 \mathrm{H}, \mathrm{s}, \mathrm{CH}_{3}\right)$. These spectroscopic data were well matched with those of 4-(3,4-dihydroxyphenyl)3-buten-2-one.

We then investigated the inhibitory effects of compounds 1 and $\mathbf{2}$ against neuraminidase from recombinant influenza A virus $\mathrm{H} 1 \mathrm{~N} 1$ (rvH1N1). A previously reported method was used for the neuraminidase inhibition assay, with minor modifications [19]. In brief, 2-(4-methylumbelliferyl)-
Table 1. H1N1 neuraminidase inhibitory activity of compounds 1 and 2

\begin{tabular}{lr}
\hline \hline Compounds & \multicolumn{1}{c}{$\mathrm{IC}_{50}(\mu \mathrm{M})^{\mathrm{a}}$} \\
\hline Inotilone (1) & $29.1 \pm 2.8$ \\
4-(3,4-Dihydroxyphenyl)-3-buten-2-one (2) & $125.6 \pm 0.6$ \\
Quercetin & $37.1 \pm 0.7$ \\
Zanamivir (nM) & $1.5 \pm 0.2$ \\
\hline
\end{tabular}

${ }^{a}$ Results are presented as mean $\mathrm{IC}_{50}$ values obtained from three independent experiments carried out in triplicate \pm SD.

$\alpha-\mathrm{D}-\mathrm{N}$-acetylneuraminic acid sodium salt (MUNANA, Cat. No M8639; Sigma, St. Louis, MO, USA), at the final concentration of $0.2 \mathrm{mM}$, was mixed with $90 \mu \mathrm{L}$ of $50 \mathrm{mM}$ Tris buffer ( $\mathrm{pH} 7.5)$ at room temperature. Ten microliters of sample solution and $50 \mu \mathrm{L}$ of rvH1N1 (50 ng/mL) were added to a well in a plate. The mixture was recorded at excitation and emission wavelengths of $365 \mathrm{~nm}$ and $445 \mathrm{~nm}$, respectively, with a POLAR OPTIMA (BMG LABTECH, Ortenberg, Germany). Zanamivir (Relenza) and quercetin, which were used as positive controls, inhibited neuraminidase with $\mathrm{IC}_{50}$ values of 0.0015 and $37.2 \mu \mathrm{M}$, respectively, in this assay system. As a result, compounds $\mathbf{1}$ and $\mathbf{2}$ exhibited neuraminidase inhibitory activity with $\mathrm{IC}_{50}$ values of 29.1 and $125.6 \mu \mathrm{M}$, respectively, in a concentration-dependent manner (Table 1).

Antiviral effect and cytotoxicity were evaluated by the SRB method using the cytopathic effect (CPE) reduction method [20]. In brief, MDCK cells were seeded onto a 96well culture plate at a concentration of $2 \times 10^{4}$ cells/well. Then, $0.09 \mathrm{~mL}$ of diluted virus suspension and $0.01 \mathrm{~mL}$ of medium supplemented with trypsin-EDTA and containing $10 \mu \mathrm{g} / \mathrm{mL}$ of compounds $\mathbf{1}$ and 2 was added to each well. After incubation at $37^{\circ} \mathrm{C}$ in $5 \% \mathrm{CO}_{2}$ for 2 days, the morphology of cells was observed under a microscope at a magnification of $32 \times 10$ (AXIOVERT10; Zeiss, Jena, Germany), and images were recorded. After MDCK cells had undergone 2-day infection with the influenza A/WS/ 33 virus, mock cells or cells treated with compounds 1, 2 or oseltamivir showed typical spread-out shapes and normal morphology. At this concentration, no signs of cytotoxicity were observed. Infection with influenza A/WS/33 virus in the absence of compounds resulted in a severe CPE (Fig. 2). Addition of compounds $\mathbf{1}$ and $\mathbf{2}$ to influenza A/WS/33 virus-infected MDCK cells inhibited the formation of a visible $\mathrm{CPE}$ with $\mathrm{IC}_{50}$ values of 61.5 and $52.3 \mu \mathrm{M}$, respectively, while oseltamivir prevented $\mathrm{CPE}$ formation with an $\mathrm{IC}_{50}$ value of $64.7 \mu \mathrm{M}$. These results revealed that compounds 1 and 2 were more effective than the positive control oseltamivir against influenza virus H1N1 (Table 2).

In conclusion, inotilone and 4-(3,4-dihydroxyphenyl)-3buten-2-one isolated from the fermentation broth of $P$. linetus were shown to be effective against $\mathrm{H} 1 \mathrm{~N} 1$ neuraminidase and the influenza A/WS/33 virus. Therefore, the potential of these compounds for use in the treatment of viral influenza infections merits additional attention. 


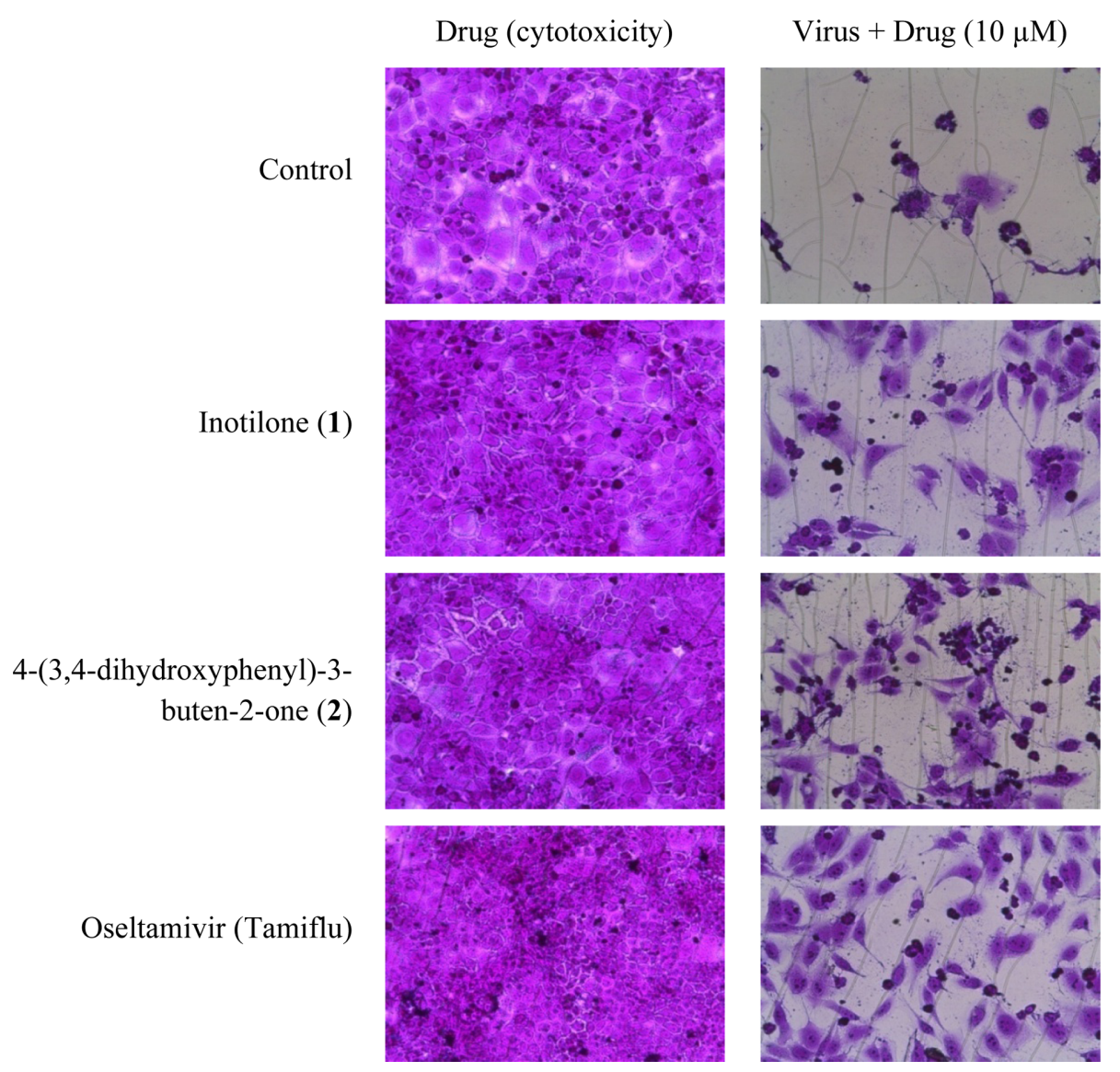

Fig. 2. Effects of compounds 1 and 2 on influenza A/WS/33 virus-induced cytopathic effect.

Table 2. Antiviral activity of compounds 1 and 2 against influenza A virus in MDCK cells ${ }^{\mathrm{a}}$

\begin{tabular}{lccc}
\hline \hline Compounds $(\mu \mathrm{M})$ & $\mathrm{CC}_{50}{ }^{\mathrm{b}}$ & $\mathrm{IC}_{50}{ }^{\mathrm{c}}$ & $\mathrm{TI}^{\mathrm{d}}$ \\
\hline Inotilone (1) & $>100$ & $61.5 \pm 6.4$ & $>1.6$ \\
4-(3,4-Dihydroxyphenyl)-3-buten-2-one (2) & $>100$ & $52.3 \pm 5.4$ & $>1.9$ \\
Oseltamivir (Tamiflu) & 176.4 & 64.7 & 1.6 \\
\hline
\end{tabular}

${ }^{\mathrm{a}}$ Results are presented as mean $\mathrm{IC}_{50}$ values obtained from three independent experiments carried out in triplicate $\pm \mathrm{SD}$.

${ }^{b}$ Concentration required to reduce cell growth by $50 \%$.

'Concentration required to inhibit virus-induced cytopathic effect by $50 \%$.

${ }^{\mathrm{d}}$ Therapeutic index $=\mathrm{CC}_{50} / \mathrm{IC}_{50}$.

\section{ACKNOWLEDGEMENTS}

This work was supported by a grant from the Technology Development Program for Bio-industry, Ministry for Food, Agriculture, Forestry and Fisheries as well as support from the Cooperative Research Program for Agriculture Science \& Technology Development (Project No. PJ009796012014), Rural Development Administration, Republic of Korea.

\section{REFERENCES}

1. Palese P, Shaw ML. Orthomyxoviridae: the viruses and their replication. In: Knipe DM, Howley PM, editors. Fields virology. 5th ed. Philadelphia: Lippincott Williams \& Wilkins; 2007. p. 1647-89.

2. Zhang J, Yu K, Zhu W, Jiang H. Neuraminidase pharmacophore model derived from diverse classes of inhibitors. Bioorg Med Chem Lett 2006;16:3009-14.

3. Moscona A. Neuraminidase inhibitors for influenza. N Engl J Med 2005;353:1363-73.

4. Nicholson KG, Wood JM, Zambon M. Influenza. Lancet 2003;362:1733-45.

5. Deng K, Zhang Y, Xie L, Peng W, Gan B, Ren Z. Simultaneous determination of five fatty acids in Phellinus sp. by highperformance liquid chromatography with photodiode-array detection. J Med Plants Res 2011;5:2816-21.

6. Zhu T, Kim SH, Chen CY. A medicinal mushroom: Phellinus linteus. Curr Med Chem 2008;15:1330-5.

7. Yeo WH, Hwang EI, So SH, Lee SM. Phellinone, a new furanone derivative from the Phellinus linteus KT\&G PL-2. Arch Pharm Res 2007;30:924-6.

8. Zheng $\mathrm{YB}, \mathrm{Lu} \mathrm{CH}$, Shen YM. New abscisic acid-related 
metabolites from Phellinus vaninii. J Asian Nat Prod Res 2012;14:613-7.

9. Yeom JH, Lee IK, Ki DW, Lee MS, Seok SJ, Yun BS. Neuraminidase inhibitors from the culture broth of Phellinus linteus. Mycobiology 2012;40:142-4.

10. Lee IK, Yun BS. Styrylpyrone-class compounds from medicinal fungi Phellinus and Inonotus spp., and their medicinal importance. J Antibiot (Tokyo) 2011;64:349-59.

11. Lee IK, Jung JY, Kim YH, Yun BS. Phellinins B and C, new styrylpyrones from the culture broth of Phellinus sp. J Antibiot (Tokyo) 2010;63:263-6.

12. Cho JY, Kwon YJ, Sohn MJ, Seok SJ, Kim WG. Phellinstatin, a new inhibitor of enoyl-ACP reductase produced by the medicinal fungus Phellinus linteus. Bioorg Med Chem Lett 2011;21:1716-8.

13. Jung JY, Lee IK, Seok SJ, Lee HJ, Kim YH, Yun BS. Antioxidant polyphenols from the mycelial culture of the medicinal fungi Inonotus xeranticus and Phellinus linteus. J Appl Microbiol 2008;104:1824-32.

14. Shon MY, Kim TH, Sung NJ. Antioxidants and free radical scavenging activity of Phellinus baumii (Phellinus of Hymenochaetaceae) extracts. Food Chem 2003;82:593-7.

15. Lee YS, Kim YH, Shin EK, Kim DH, Lim SS, Lee JY, Kim JK. Anti-angiogenic activity of methanol extract of Phellinus linteus and its fractions. J Ethnopharmacol 2010;131:56-62.

16. Kim HG, Yoon DH, Lee WH, Han SK, Shrestha B, Kim CH, Lim MH, Chang W, Lim S, Choi S, et al. Phellinus linteus inhibits inflammatory mediators by suppressing redox-based NF- $\kappa \mathrm{B}$ and MAPKs activation in lipopolysaccharide-induced RAW 264.7 macrophage. J Ethnopharmacol 2007;114:307-15.

17. Ichinohe T, Ainai A, Nakamura T, Akiyama $\mathrm{Y}$, Maeyama J, Odagiri T, Tashiro M, Takahashi H, Sawa H, Tamura S, et al. Induction of cross-protective immunity against influenza $\mathrm{A}$ virus $\mathrm{H} 5 \mathrm{~N} 1$ by an intranasal vaccine with extracts of mushroom mycelia. J Med Virol 2010;82:128-37.

18. Huang GJ, Huang SS, Deng JS. Anti-inflammatory activities of inotilone from Phellinus linteus through the inhibition of MMP-9, NF- $\mathrm{BB}$, and MAPK activation in vitro and in vivo. PLoS One 2012;7:e35922.

19. Kim JY, Jeong HJ, Park JY, Kim YM, Park SJ, Cho JK, Park $\mathrm{KH}$, Ryu YB, Lee WS. Selective and slow-binding inhibition of shikonin derivatives isolated from Lithospermum erythrorhizon on glycosyl hydrolase 33 and 34 sialidases. Bioorg Med Chem 2012;20:1740-8.

20. Choi HJ, Song JH, Park KS, Kwon DH. Inhibitory effects of quercetin 3-rhamnoside on influenza A virus replication. Eur J Pharm Sci 2009;37:329-33. 